\title{
Gastric Lymphangioma
}

National Cancer Institute

\section{Source}

National Cancer Institute. Gastric Lymphangioma. NCI Thesaurus. Code C5482.

A lymphangioma arising from the stomach. 